\title{
Developmental Regulation of Protein Kinase B Activation Is Isoform Specific in Skeletal Muscle of Neonatal Pigs
}

\author{
AGUS SURYAWAN AND TERESA A. DAVIS \\ USDA/ARS Children's Nutrition Research Center, Department of Pediatrics, Baylor College of Medicine, \\ Houston, Texas 77030
}

\begin{abstract}
ABST
The postprandial activation of the insulin signaling pathway
that leads to translation initiation is enhanced in skeletal muscle
of the neonate and decreases with development in parallel with
the developmental decline in muscle protein synthesis. Our
previous study showed that the activity of protein kinase B
(PKB), a major insulin signaling component, was higher in 7-
than in 26-d-old pigs. To examine the molecular mechanisms
involved, we determined PKB isoform abundance and phosphor-
ylation state, the abundance of its kinases, and PKB's association
with its kinases. The abundances of total PKB, PKB $\alpha$, and PKB $\gamma$
were higher in muscle of 7- than in 26-d-old pigs whereas PKB $\beta$
abundance was similar in the two age groups. PKB phosphory-
lation at Thr308 was higher in 7- than in 26-d-old pigs but PKB
phosphorylation at Ser473 was similar in both age groups. The
association of PKB with 3'-phosphoinositide-dependent kinase-1
(PDK-1), a kinase that phosphorylates PKB at Thr308, and
PDK-1 abundance were higher in 7- than in 26-d-old pigs.
\end{abstract}
Moreover, PDK-1 phosphorylation at Ser-241, a site that is crucial for PDK-1 activation, was higher in 7- than in 26-d-old pigs. However, the association of PKB with integrin-linked kinase (ILK), a kinase that potentially phosphorylates PKB at Ser473, and ILK abundance were similar in both age groups. The result suggests that the developmental change in $\mathrm{PKB}$ activation is isoform specific and involves regulation by PDK-1. (Pediatr Res 58: 719-724, 2005)

Abbreviations
ILK, integrin-linked kinase
PKB, protein kinase B
PKB $\boldsymbol{\alpha}$, protein kinase B alpha
PKB $\boldsymbol{\beta}$, protein kinase B beta
PKB $\boldsymbol{\gamma}$, protein kinase B gamma
PDK-1, 3'-phosphoinositide-dependent kinase-1

The enhanced activation of the insulin signaling pathway leading to translation initiation after food consumption plays an important role in the enhanced responsiveness of protein synthesis to feeding in skeletal muscle of the neonate (1-5). We have shown that the feeding-induced activation of the insulin receptor, insulin receptor substrate-1 (IRS-1), and phosphatidylinositol 3-kinase (PI 3-kinase), as well as the abundance of the insulin receptor, are enhanced in skeletal muscle of neonatal pigs and decrease markedly with development. This response to feeding is mediated by the postprandial rise in insulin level; indeed, amino acids do not influence the activation of early steps of the insulin signaling pathway (6). The developmental decline in the feeding-induced activation of up-stream insulin-signaling components parallels the develop-

Received November 22 2004; accepted February 14, 2005.

Correspondence: Teresa A. Davis, Ph.D., USDA/ARS Children's Nutrition Research Center, Baylor College of Medicine, Department of Pediatrics/Nutrition, 1100 Bates St., Suite 9064, Houston, TX 77030-2600; e-mail: tdavis@bcm.tmc.edu

Supported by funds from the National Institutes of Health (grant no. RO1-AR44474) and the U.S. Department of Agriculture (grant no. 6250-51000).

DOI: 10.1203/01.PDR.0000180536.51032.AB mental decline in the feeding-induced activation of downstream signaling proteins leading to the stimulation of translation initiation in skeletal muscle and the developmental decrease in the ability of insulin to stimulate muscle protein synthesis $(2-5,7)$. Furthermore, the enhanced activation of the insulin receptor in muscle of the neonate is associated with reduced activity of protein-tyrosine-phosphatase-1B (PTP-1B), which functions to dephosphorylate the activated insulin receptor (8). On the other hand, insulin/IGF-I hybrid receptor abundance, which has been associated with insulin resistance, is not reduced in neonatal muscle (9). However, the signaling components that regulate the developmental changes in downstream signaling proteins, such as $\mathrm{PKB}$, have not been fully elucidated.

$\mathrm{PKB}$, which is also known as RAC or Akt, is a $57-\mathrm{kD}$ phospholipid-dependent serine/threonine kinase that is activated by growth factors, including insulin, in a PI 3-kinasedependent manner (10). Studies have shown that PKB plays a major role in linking PI 3-kinase activation to multiple biologic functions of insulin such as glucose transport, glycogen synthesis, and protein synthesis in skeletal muscle, a major target 
of insulin action $(11,12)$. There are three mammalian isoforms of $\mathrm{PKB}$, namely $\operatorname{PKB} \alpha, \operatorname{PKB} \beta$, and $\operatorname{PKB} \gamma(13-15)$. They are widely expressed in mammalian tissues and each isoform is composed of an N-terminal phosphatidylinositol $(3,4,5) \mathrm{P} 3$ - and phosphatidylinositol $(3,4,5) \mathrm{P} 2$-binding pleckstrin homology (PH) domain and a C-terminal kinase domain (16). Almost all of the studies of this enzyme have focused on the PKB $\alpha$ isoform. Recently, $\mathrm{PKB} \alpha$-deficient mice were shown to be significantly smaller than wild-type mice (17) whereas $\operatorname{PKB} \beta$ deficient mice were insulin resistant but of normal size (18). This suggests that it is the $\mathrm{PKB} \alpha$ isoform that is involved in the regulation of protein synthesis.

Activation of PKB involves a series of events $(19,20)$. First, the kinase is constitutively phosphorylated on Ser-124 and Thr-450 in a PH-dependent, growth factor-independent fashion. Second, the kinase is recruited to the membrane via binding of its $\mathrm{PH}$ domain to phospholipids by a PI-3-kinasedependent mechanism. Third, the kinase is phosphorylated on Thr-308 and Ser-473 in a growth factor-dependent manner. Although the phosphorylation of Thr-308 and Ser-473 are required for full activation of $\mathrm{PKB}$, the contribution of each site is not equal, inasmuch as phosphorylation of Thr-308 alone increases PKB activity while phosphorylation of Ser- 473 does not significantly stimulate PKB $(19,21)$. The phosphorylation of Thr-308 is facilitated by PDK1 (22) whereas Ser-473 may be phosphorylated by ILK (23).

Our previous studies showed that the enzyme activity of PKB in skeletal muscle is markedly higher in 7- compared with 26-d-old pigs (4), consistent with the higher fractional rate of protein synthesis in skeletal muscle of 7- than in 26-d-old pigs (1). In this study, we investigated the molecular mechanism by which feeding, via the postprandial rise of insulin, activates $\mathrm{PKB}$, leading to an increase in translation initiation processes in neonatal muscle. The results indicate that the developmental changes in the abundance of $\operatorname{PKB} \alpha, \operatorname{PKB} \gamma$, and PDK-1, the phosphorylation of PKB on Thr308 and PDK-1 on Ser241, and the association of PKB with PDK-1 contribute to the enhanced PKB activity in skeletal muscle of neonatal pigs.

\section{METHODS}

Animals. Eight crossbred (Landrace $\times$ Yorkshire $\times$ Duroc $\times$ Hampshire) pregnant sows (Agriculture Headquarters, Texas Department of Criminal Justice, Huntsville, TX) were housed in lactation crates in individual, environmentally controlled rooms 2 wk before farrowing. Sows were fed a commercial diet (5084, PMI Feeds, Richmond, IN) and provided water ad libitum. After farrowing, piglets remained with the sow but were not allowed access to the sow's diet. A total of eight piglets from four litters, weighing 2-8 $\mathrm{kg}$, were studied at 7 and $26 \mathrm{~d}$ of age, respectively.

Pigs within each litter were randomly assigned to one of two treatment groups ( $n=4$ per age group), and were fasted for $18 \mathrm{~h}$ and then fed for $1.5 \mathrm{~h}$ after an 18-h fast. Water was provided throughout the fasting period. After the 18-h fast, pigs were given two gavage administrations of $30 \mathrm{~mL} / \mathrm{kg}$ body weight of mature porcine milk (University of Nebraska, Lincoln, NE) at 60-min intervals. Pigs were killed $30 \mathrm{~min}$ after the second gavage feeding. Samples of longissimus dorsi muscle was rinsed in ice-cold saline and rapidly frozen. The protocol was approved by the Animal Care and Use Committee of Baylor College of Medicine and was conducted in accordance with the National Research Council's Guide for the Care and Use of Laboratory Animals.

Materials. BioMag goat anti-mouse IgG and goat anti-rabbit IgG magnetic beads were obtained from Polysciences (Warrington, PA) and the magnetic sample rack was from Promega (Madison, WI). Reagents for SDS-PAGE were from Bio-Rad Laboratories (Richmond, CA). The protein assay kit was purchased from Pierce (Rockford, IL). Anti-PKB $\alpha$, anti-PKB $\beta$, and anti-PKB $\gamma$ antibodies were obtained from Santa Cruz Biotechnology (Santa Cruz, CA). Anti-PDK1 and anti-ILK antibodies and an anti-PKB antibody that detects total levels of endogenous $\mathrm{PKB} \alpha, \mathrm{PKB} \beta$, and $\mathrm{PKB} \gamma$ proteins were obtained from Cell Signaling (Beverly, MA). PKB-phospho-specific antibodies (Ser473 and Thr-308) that recognize all isoforms were purchased from R \& D Systems (Minneapolis, MN). The enhanced chemiluminescence Western blotting detection kit (ECL-Plus) was obtained from Amersham (Arlington Heights, IL). Other chemicals and reagents were from Sigma Chemical Co. (St. Louis, MO).

Preparation of tissue extracts. Tissue samples were prepared as described previously (5). Briefly, samples of frozen muscle and liver were pulverized and homogenized in ice-cold buffer containing (in mM) 50 HEPES, pH 7.4, $150 \mathrm{NaCl}, 10$ sodium pyrophosphate, $2 \mathrm{Na}_{3} \mathrm{VO}_{4}, 1 \mathrm{MgCl}_{2}, 1 \mathrm{CaCl}_{2}, 10 \mathrm{NaF}$, 5 Na-EDTA, 2 phenylmethylsulfonyl fluoride, $25 \mu \mathrm{g} / \mathrm{mL}$ leupeptin, $1 \%$ IGEPAL, and $10 \%$ glycerol. The homogenate was incubated for $45 \mathrm{~min}$ at $4^{\circ} \mathrm{C}$ with gentle mixing and then centrifuged at $35,000 \mathrm{~g}$ for $1 \mathrm{~h} \mathrm{at} 4^{\circ} \mathrm{C}$. The supernatant was collected, and an aliquot was assayed for protein concentration using the Pierce protein assay kit. Supernatants were used to determine the abundance of PKB isoform, PDK-1, and ILK and the phosphorylation of PKB and PDK1. The supernatants were also used for immunoprecipitation.

Immunoprecipitation. To determine the association of PKB with PDK-1 and ILK, protein samples were immunoprecipitated with an anti-PKB antibody that recognizes all isoforms. The immunoprecipitation procedure was conducted as described by Fox et al. (24). Briefly, equal amounts of membrane protein $(500 \mu \mathrm{g}$ protein in $500 \mu \mathrm{L}$ buffer $)$ were incubated overnight at $4^{\circ} \mathrm{C}$ with an anti-PKB antibody in 2.5\% Triton X-100/PBS. BioMag goat anti-rabbit IgG magnetic beads $(1 \mathrm{~mL} /$ tube) were washed three times in low-salt buffer $(20$ $\mathrm{mM}$ Tris, $150 \mathrm{mM} \mathrm{NaCl}, 5 \mathrm{mM}$ disodium EDTA, $0.5 \%$ Triton $\mathrm{X}-100$, and $0.1 \% \beta$-mercaptoethanol, $\mathrm{pH} 7.4$ ) with the use of a magnetic sample rack and were resuspended in $500 \mu \mathrm{L}$ of low-salt buffer containing $1 \%$ dry skim milk. Each sample was added to $500 \mu \mathrm{L}$ of resuspended beads and rocked for at least $1 \mathrm{~h}$ at $4^{\circ} \mathrm{C}$. The beads were captured using a magnetic rack and were washed twice in low-salt buffer and once in high-salt buffer $(50 \mathrm{mM}$ Tris, $500 \mathrm{mM}$ $\mathrm{NaCl}, 5 \mathrm{mM}$ disodium EDTA, $1 \%$ Triton $\mathrm{X}-100,0.6 \%$ sodium deoxycholate, $0.1 \%$ SDS, and $0.04 \% \beta$-mercaptoethanol, $\mathrm{pH} 7.4$ ). The captured beads were resuspended in $100 \mu \mathrm{L} 1 \times$ sample buffer [2\% SDS, $100 \mathrm{mM}$ Tris $\mathrm{HCl}, \mathrm{pH} 6.8$, $5 \% \beta$-mercaptoethanol, $12 \%$ (vol/vol) glycerol, and $0.02 \%(\mathrm{wt} / \mathrm{vol}) \mathrm{Bromphe}-$ nol blue], boiled for $5 \mathrm{~min}$, and stored at $-80^{\circ} \mathrm{C}$ until electrophoresis.

Western blot analysis. Equal amounts of protein were subjected to SDSPAGE (8\% wt/vol; Mini-PROTEAN II electrophoresis system, Bio-Rad), as described by Laemmli (25). Electrophoretic separation was carried out in $1 \%$ SDS, $25 \mathrm{mM}$ Tris, and $200 \mathrm{mM}$ glycine ( $\mathrm{pH} \mathrm{8.4)}$ at $200 \mathrm{~V}$ for $45-60 \mathrm{~min}$ at room temperature. The proteins were then transferred to an activated polyvinylidene difluoride (PVDF) membrane (Immobilon-P; Millipore, Bedford, MA) in $25 \mathrm{mM}$ Tris, $192 \mathrm{mM}$ glycine, and 20\% methanol (vol/vol; $\mathrm{pH} 8.3$ ) for $1 \mathrm{~h}$ at $4^{\circ} \mathrm{C}$. The membrane was incubated for $1 \mathrm{~h}$ at room temperature in a Tris-buffered saline-Tween 20 solution (TBS-T) containing $10 \mathrm{mM}$ Tris, 0.5 $\mathrm{M} \mathrm{NaCl}$, and $0.5 \%$ Tween 20, pH 7.4, with 5\% (wt/vol) nonfat dried milk added. After the blocking step, the membrane was incubated with one primary antibody (anti-PKB, anti-PDK-1, or anti-ILK antibodies) for $1 \mathrm{~h}$ and washed four times in rinsing solution. Membranes were then incubated with secondary antibody (horseradish peroxidase-conjugated $\mathrm{IgG}$ fraction of goat anti-rabbit IgG or goat anti-mouse IgG) diluted 1:2000 in TBS-T. The membranes were then washed in TBS-T three times for $10 \mathrm{~min}$ and developed with an enhanced chemiluminescence detection kit (ECL-Plus, Amersham Pharmacia, Piscataway, NJ) before exposure onto Kodak-X-Omat film. The blots were quantified by computerized densitometry (Molecular Dynamics, Sunnyvale, CA).

Measurement of site-specific phosphorylation of $P K B$ and PDK-1. Phosphorylation of PKB was determined by Western blot analysis using antibodies specific for PKB when it is phosphorylated at Ser-473 or Thr-308. Phosphorylation of PDK-1 on Ser-241, a residue that is crucial for its activation, was assessed by Western blot analysis using an antibody specific for PDK-1 phosphorylated on Ser-241. The membranes were then stripped and reprobed with an anti-PKB antibody or anti-PDK-1 antibody that recognizes both the phosphorylated and unphosphorylated forms of the proteins. Values obtained using the anti-phospho-PKB antibodies or anti-phospho-PDK-1 antibody were normalized for the total amount of PKB or PDK-1 present in the samples.

Data analysis. To test for differences between age groups, $t$ test was used. Probability values of $<0.05$ were considered statistically significant. Data are presented as means $\pm \mathrm{SE}$.

\section{RESULTS}

PKB isoforms in pig skeletal muscle. Because geneknockout studies indicate that each PKB isoform regulates 
different metabolic functions, we determined the abundances of individual PKB isoforms and total (all) PKB isoforms using Western Blot analysis. As previously reported in a muscle cell line (26) and adult rat skeletal muscle (27), in this study we found that all PKB isoforms are expressed in neonatal pig skeletal muscle. The abundance of total PKB, which was detected by an antibody that recognizes all isoforms, was significantly higher in 7- compared with 26-d-old pigs (Fig. $1 A$ ). The abundances of $\mathrm{PKB} \alpha$ and $\mathrm{PKB} \gamma$ were also significantly higher in 7- compared with 26-d-old-pigs (Fig. $1 B$ and Fig. $1 D$, respectively). On the other hand, the abundance of $\operatorname{PKB} \beta$ was similar in both age groups (Fig. 1C). In this experiment, we did not quantify the relative abundance of each PKB isoform because the effectiveness of the antibody for each isoform may differ.

Feeding induces PKB phosphorylation in an agedependent manner. We have shown previously that feeding stimulates the activity of PKB and that this effect is reduced with development (4). Since both the phosphorylation of Thr308 and Ser-473 of PKB are needed for full activation of this enzyme (21), we determined PKB phosphorylation using a phospho-serine-antibody that recognizes all isoforms (phospho-PKB $\alpha$-Ser-473, phospho-PKB $\beta$-Ser-474, and phosphoPKB $\gamma$-Ser-472), and a phospho-threonine-antibody that recognizes all isoforms (phospho-PKB $\alpha$-Thr-308, phospho-PKB $\beta$ Thr-309, and phospho-PKB $\gamma$-Thr-305). The phosphorylation of Thr-308 of PKB was significantly higher in 7- compared with 26-d-old pigs (Fig. 2A). However, we did not detect any difference in the PKB phosphorylation at Ser-473 in the two age groups (Fig. 2B). This suggests that in skeletal muscle of neonatal pigs, the phosphorylation of PKB at Thr-308, but not at Ser-473, regulates enzyme activity.
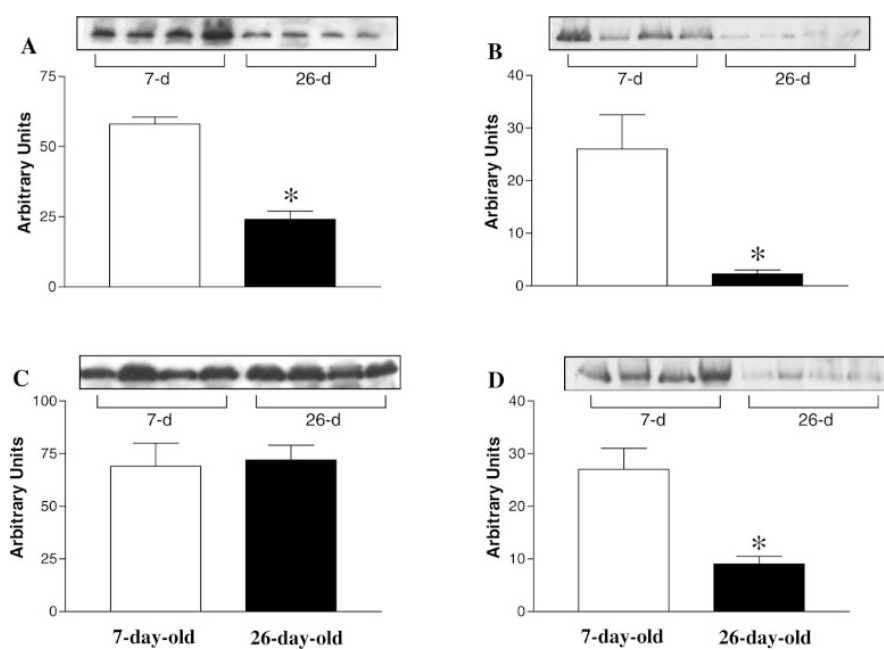

Figure 1. Determination of PKB isoform abundance in skeletal muscle of neonatal pigs. Equal amounts of protein were subjected to SDS-PAGE followed by immunoblot analysis with anti-PKB (total), $\operatorname{PKB} \alpha, \operatorname{PKB} \beta$, or $\operatorname{PKB} \gamma$. The abundance of $(A)$ total PKB (all three PKB isoforms), (B) $\mathrm{PKB} \alpha$ isoform, (C) $\mathrm{PKB} \beta$ isoform, and $(D) \mathrm{PKB} \gamma$ isoform in skeletal muscle of 7- and 26-d-old pigs. Western blots are shown above each graph. Results are means $\pm \mathrm{SE}$ in arbitrary densitometric units (four animals per group) $\left({ }^{*} p<0.05\right)$. A power test of analysis on data in $C$ indicates that there is a $92 \%$ probability that both groups are not significantly different and that an equal sample size (for both groups) of 646 would be needed to obtain significance at $p=0.05$.
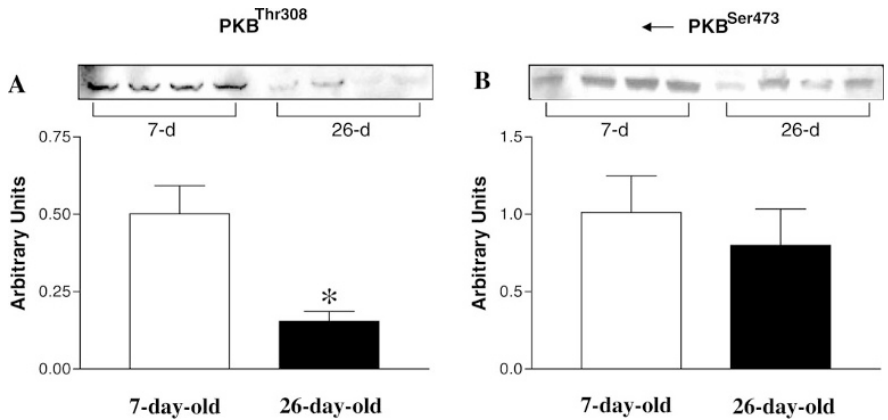

Figure 2. Assessment of phosphorylation status of Ser-473 and Thr-308 on PKB in skeletal muscle of neonatal pigs. PKB phosphorylation on Ser-473 (A) and Thr-308 $(B)$ were measured by Western blot analysis using antibodies that recognize PKB only when Ser-473 or Thr-308 is phosphorylated. Western blots are shown above each graph. Results were normalized by dividing arbitrary unit of phospho-PKB with arbitrary unit of total PKB in the samples. Results are means \pm SE in arbitrary densitometric units (four animals per group) $\left({ }^{*} p<0.05\right)$. A power test of analysis on data in $B$ indicates that there is an $86 \%$ probability that both groups are not significantly different and that an equal sample size (for both groups) of 66 would be needed to obtain significance at $p=0.05$.

PDK-1 and ILK abundance, their association with PKB, and PDK-1 phosphorylation in skeletal muscle of neonatal pigs. The association of a kinase with its target is one of the crucial steps necessary for the kinase to phosphorylate its substrate $(28,29)$. Therefore, we measured the abundance of PDK-1 and its association with PKB. The abundance of PDK-1, the kinase that facilitates the phosphorylation of PKB on Thr-308, was significantly higher in 7- compared with 26-d-old pigs (Fig. 3A). To determine the association of PKB with PDK-1, we immunoprecipitated PKB from tissue homogenates using an antibody that recognize all isoforms. PKB immunoprecipitates were separated using SDS-PAGE followed by immunoblotting using an anti-PDK-1 antibody. Figure $4 A$ shows that PDK-1 was present in PKB immunoprecipitates and that this kinase-substrate association was significantly higher in 7- compared with 26-d-old pigs. These data are consistent with the higher PKB phosphorylation at Thr-308 in 7- compared with 26-d-old pigs. To further confirm the role of PDK-1 in the activation of PKB phosphorylation at Thr-308, we determined the PDK-1 phosphorylation at Ser-241, a site that is crucial for PDK-1 enzyme activity (30). As shown in Figure $4 C$, PDK-1 phosphorylation was markedly higher in
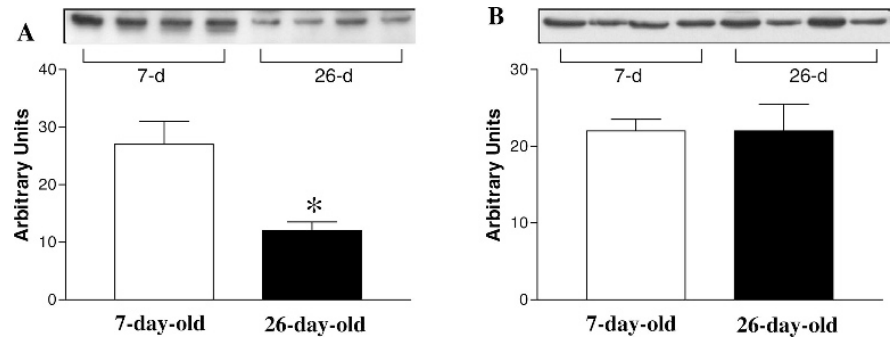

Figure 3. Determination of PDK-1 and ILK abundance in skeletal muscle of neonatal pigs. The abundance of PDK-1 $(A)$ and ILK $(B)$ were determined by subjecting equal amounts of protein to SDS-PAGE followed by immunoblot analysis with anti-PDK-1 or ILK, respectively. Western blots are shown above each graph. Results are means \pm SE in arbitrary densitometric units (four animals per group) $(* p<0.05)$. 
A

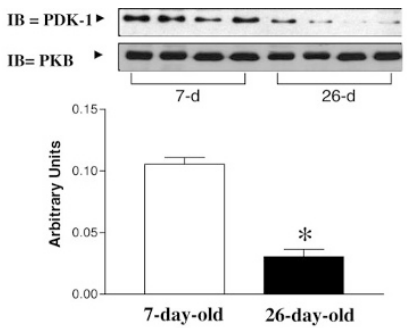

B $\mathrm{IB}=\mathrm{ILK}$ r
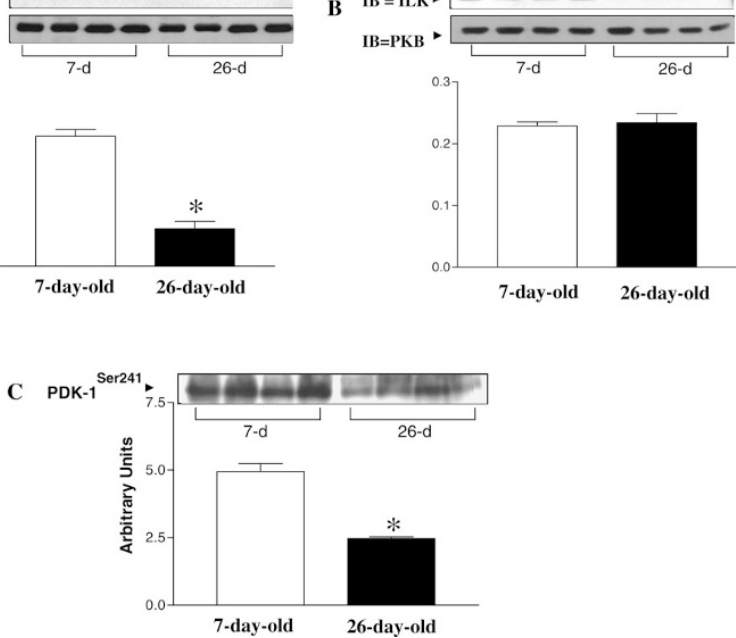

Figure 4. Evaluation of the association of PKB with PDK-1 and with ILK and the phosphorylation of PDK-1. The protein-protein interaction between PKB and PDK-1 $(A)$ and between PKB and ILK $(B)$ was determined by immunoprecipitation using anti-PKB followed by Western blot analysis with anti-PDK-1 or anti-ILK, respectively. Results were normalized by dividing arbitrary units of PDK-1-PKB or ILK-1-PKB with arbitrary units of total PKB in immunoprecipitates. PDK-1 phosphorylation on Ser-241 (C) was measured by Western blot analysis using antibody that recognizes PDK-1 only when Ser-241 is phosphorylated. Results were normalized by dividing arbitrary unit of phospho-PDK-1 with arbitrary unit of total PDK-1 in the samples. Results are means $\pm \mathrm{SE}$ in arbitrary densitometric units (four animals per group) ${ }^{*} p$ $<0.05$ ). A power test of analysis on data in $B$ indicates that there is a $91 \%$ probability that both groups are not significantly different and that an equal sample size (for both groups) of 240 would be needed to obtain significance at $p=0.05$.

7- compared with 26-d-old pigs. This indirectly suggests that PDK-1 enzyme activity was higher in 7- compared with 26-dold pigs.

Although the role of PDK-1 in stimulating PKB phosphorylation at Thr-308 is well established (31), the kinase that is responsible for PKB phosphorylation at Ser-473 is still controversial $(32,33)$. One possible candidate that has been implicated in this role is ILK (34). As shown in Figure $3 B$, ILK abundance was similar in 7- and 26-d-old pigs. We also found that ILK was present in PKB immunoprecipitates (Fig. 4B), indicating an association between these proteins. Consistent with the data for PKB phosphorylation at Ser-473, the association of ILK with PKB was similar in both age groups. These results demonstrate the differential role of $\mathrm{PKB}$ phosphorylation at Ser-473 and Thr-308 in the regulation of PKB enzyme activity in vivo.

\section{DISCUSSION}

Recent studies from our laboratory have shown an enhanced activation of the insulin-signaling pathway leading to translation initiation in skeletal muscle of the neonatal pig after food consumption $(2,4,5)$. This feeding-induced activation of the insulin receptor, IRS-I, PI 3-kinase, and protein kinase B decreases with development in parallel with the developmental decline in the feeding-induced activation of translation initiation factors that regulate the binding of mRNA to the $43 \mathrm{~S}$ ribosomal complex. These developmental changes parallel the developmental changes in the ability of feeding and insulin infusion to stimulate protein synthesis and are specific to skeletal muscle $(1,7,35)$. Because of the profound developmental decline in the feeding-induced activation of the insulinsignaling cascade, including the enzyme activity of PKB (4), it was crucial that we ascertain the mechanism involved in this developmental decline in PKB activation. Furthermore, since genetic and biochemical studies have suggested differential functions of PKB isoforms $(18,26,36,37)$, we determined the effect of development on PKB isoform abundance in neonatal pigs.

We found that all three PKB isoforms were expressed in skeletal muscle of neonatal pigs. Although studies in muscle cell culture (26) and adult animals (27) observed the expression of three PKB isoforms, to the best of our knowledge, this is the first study that documented a developmental change in two $\mathrm{PKB}$ isoforms $(\mathrm{PKB} \alpha$ and $\mathrm{PKB} \gamma)$ in skeletal muscle. The developmental change in $\mathrm{PKB} \alpha$ abundance parallels the decline in muscle protein synthesis and supports the early observations in $\mathrm{PKB} \alpha$-null mice that indicate that $\mathrm{PKB} \alpha$ is a regulator of animal growth (17). Furthermore, Faridi et al. (38) reported recently that the expression of constitutively active $\operatorname{PKB} \alpha$ and $\mathrm{PKB} \gamma$ in MCF-7 cells and $\mathrm{H} 4 \mathrm{IIE}$ rat hepatoma cells, respectively, increased cell size by approximately 2 -fold. This doubling of cell size was achieved by a PKB-induced stimulation of protein synthesis and inhibition of protein degradation. The results of the current study suggest that $\mathrm{PKB} \gamma$ also has a potential role in the regulation of protein synthesis and cell growth in the whole animal. We also found that there was no effect of development on the abundance of $\operatorname{PKB} \beta$. Genetic studies using cell cultures (37) and intact mice $(18,39)$ suggest that $\mathrm{PKB} \beta$ plays a crucial role in the regulation of glucose metabolism. Our current data are consistent with our previous studies, which showed that the effect of development on amino acids disposal is much more profound than that for glucose (40).

The phosphorylation of PKB at both Ser-473 and Thr-308 are required for full activation of PKB (21). The contribution of each site is not equal. Studies have shown that although phosphorylation on Thr-308 alone is able to increase PKB activity, the phosphorylation of PKB on Ser-473 alone does not significantly stimulate the activity of this enzyme $(19,21)$. Those observations are consistent with our results, which indicate that the enhanced PKB activity in neonatal pigs (4) is due to an increased phosphorylation of PKB on Thr-308, but not on Ser-473. However, our data also suggest that the PKB phosphorylation on both sites is required for the postprandialinduced PKB activation in neonatal pigs.

It is widely accepted that the molecular links between PI 3-kinase and PKB phosphorylation are phosphoinositidedependent kinases such as PDK-1 (41). In this study, we found that PDK-1 abundance, PDK-1 phosphorylation at Ser-241, and PDK-1 association with PKB were significantly higher in 7- compared with 26-d-old pigs. Because a specific-site mutation study showed that Ser-241 is a crucial site for PDK-1 activity (30), our current observations indirectly indicate that PDK-1 activity is also higher in 7- compared with 26-d-old pigs. All of these results are consistent with our finding that 
PKB phosphorylation at Thr-308 is higher in muscle of 7- than in 26-d-old pigs. The molecular mechanism by which kinase(s) phosphorylate PKB at Ser-473 site is still debatable $(32,33)$. Recent evidence suggests that ILK directly or indirectly (as an adaptor protein) phosphorylates PKB at Ser-473 (42-44). Using human platelets, Barry and Gibbins (45) demonstrated that ILK physically associates with $\mathrm{PKB}$ and speculated that a tertiary complex between PDK-1, ILK, and PKB was necessary for PKB activation. Our results show that neither ILK abundance nor ILK association with PKB was significantly different in 7- and 26-d-old pigs, consistent with the lack of effect of age on PKB phosphorylation at Ser-473.

In summary, we found that all three PKB isoforms were expressed in neonatal skeletal muscle but that only $\operatorname{PKB} \alpha$ and $\operatorname{PKB} \gamma$ forms were developmentally regulated. Because the rates of muscle growth and protein synthesis decrease with development and $\mathrm{PKB} \alpha$-null mice exhibit retarded growth (17), it seems likely that it is the $\alpha$ isoform, rather than the $\beta$ isoform of $\mathrm{PKB}$, that regulates muscle protein synthesis. Our studies also suggest that the developmental decline in PKB activity in muscle that we previously reported (4) is likely due to a developmental decline in the phosphorylation of PKB on Thr-308, rather than Ser-473. The developmental decline in PDK-1 abundance, association of PKB with PDK-1, and phosphorylation of PKD-1 at Ser-241 likely contribute to the developmental change in PKB activity. On the other hand, the abundance of ILK and its association with PKB do not appear to be developmentally regulated, consistent with the lack of developmental change in PKB phosphorylation at Ser-473, a purported site of ILK action. These results represent novel findings of the developmental regulation of $\mathrm{PKB}$ and suggest that PKB plays an important role in the enhanced activation of the insulin signaling pathway leading to translation initiation in skeletal muscle of the neonate. The enhanced activation of these signaling components likely contribute to the efficient utilization of nutrients for growth and rapid gain in protein mass in skeletal muscle of the neonate.

Acknowledgments. The authors thank H. Nguyen and W. Liu for laboratory assistance, J. Stubblefield for care of animals, and L. Weiser for secretarial assistance.

\section{REFERENCES}

1. Davis TA, Burrin DG, Fiorotto ML, Nguyen HV 1996 Protein synthesis in skeletal muscle and jejunum is more responsive to feeding in 7- than in 26-day-old pigs. Am J Physiol Endocrinol Metab 270:E802-E809

2. Davis TA, Nguyen HV, Suryawan A, Bush JA, Jefferson LS, Kimball SR 2000 Developmental changes in the feeding-induced stimulation of translation initiation in muscle of neonatal pigs. Am J Physiol Endocrinol Metab 279:E1226-E1234

3. Kimball SR, Jefferson LS, Nguyen HV, Suryawan A, Bush JA, Davis TA 2000 Feeding stimulates protein synthesis in muscle and liver of neonatal pigs through an mTOR-dependent process. Am J Physiol Endocrinol Metab 279:E1080-E1087

4. Kimball SR, Farrell PA, Nguyen HV, Jefferson LS, Davis TA 2002 Developmental decline in components of signal transduction pathways regulating protein synthesis in pig muscle. Am J Physiol Endocrinol Metab 282:E585-E592

5. Suryawan A, Nguyen HV, Bush JA, Davis TA 2001 Developmental changes in the feeding-induced activation of the insulin-signaling pathway in neonatal pigs. Am J Physiol Endocrinol Metab 281:E908-E915

6. Suryawan A, O'Connor PM, Kimball SR, Bush JA, Nguyen HV, Jefferson LS, Davis TA 2004 Amino acids do not alter the insulin-induced activation of the insulin signaling pathway in neonatal pigs. J Nutr 134:24-30

7. Davis TA, Fiorotto ML, Beckett PR, Burrin DG, Reeds PJ, Wray-Cahen D, Nguyen HV 2001 Differential effects of insulin on peripheral and visceral tissue protein synthesis in neonatal pigs. Am J Physiol Endocrinol Metab 280:E770-E779
8. Suryawan A, Davis TA 2003 Protein-tyrosine-phosphatase 1B activation is regulated developmentally in muscle of neonatal pigs. Am J Physiol Endocrinol Metab 284:E47-E54

9. Suryawan A, Nguyen HV, Orellana RA, Bush JA, Davis TA 2003 Insulin/insulin-like growth factor-I hybrid receptor abundance decreases with development in suckling pigs. J Nutr 133:2783-2787

10. Scheid MP, Woodgett JR 2003 Unravelling the activation mechanisms of protein kinase B/Akt. FEBS Lett 546:108-112

11. Ueki K, Yamamoto-Honda R, Kaburagi Y, Yamauchi T, Tobe K, Burgering BM, Coffer PJ, Komuro I, Akanuma Y, Yazaki Y, Kadowaki T 1998 Potential role of protein kinase B in insulin-induced glucose transport, glycogen synthesis, and protein synthesis. J Biol Chem 273:5315-5322

12. Hajduch E, Alessi DR, Hemmings BA, Hundal HS 1998 Constitutive activation of protein kinase $\mathrm{B}$ alpha by membrane targeting promotes glucose and system $\mathrm{A}$ amino acid transport, protein synthesis, and inactivation of glycogen synthase kinase 3 in L6 muscle cells. Diabetes 47:1006-1013

13. Coffer PJ, Woodgett JR 1991 Molecular cloning and characterization of a novel putative protein-serine kinase related to the cAMP-dependent and protein kinase C families. Eur J Biochem 201:475-481

14. Cheng JQ, Godwin AK, Bellacosa A, Taguchi T, Franke TF, Hamilton TC, Tsichlis PN, Testa JR 1992 AKT2, a putative oncogene encoding a member of a subfamily of protein-serine/threonine kinases, is amplified in human ovarian carcinomas. Proc Natl Acad Sci U S A 89:9267-9271

15. Brozinick JT Jr, Roberts BR, Dohm GL 2003 Defective signaling through Akt-2 and -3 but not Akt-1 in insulin-resistant human skeletal muscle: potential role in insulin resistance. Diabetes 52:935-941

16. Marte BM, Downward J 1997 PKB/Akt: connecting phosphoinositide 3-kinase to cell survival and beyond. Trends Biochem Sci 22:355-358

17. Cho H, Thorvaldsen JL, Chu Q, Feng F, Birnbaum MJ 2001 Akt1/PKBalpha is required for normal growth but dispensable for maintenance of glucose homeostasis in mice. J Biol Chem 276:38349-38352

18. Cho H, Mu J, Kim JK, Thorvaldsen JL, Chu Q, Crenshaw EB 3rd, Kaestner KH, Bartolomei MS, Shulman GI, Birnbaum MJ 2001 Insulin resistance and a diabetes mellitus-like syndrome in mice lacking the protein kinase Akt2 (PKB beta). Science 292:1728-1731

19. Bellacosa A, Chan TO, Ahmed NN, Datta K, Malstrom S, Stokoe D, McCormick F, Feng J, Tsichlis P 1998 Akt activation by growth factors is a multiple-step process: the role of the PH domain. Oncogene 17:313-325

20. Hill MM, Andjelkovic M, Brazil DP, Ferrari S, Fabbro D, Hemmings BA 2001 Insulin-stimulated protein kinase B phosphorylation on Ser-473 is independent of its activity and occurs through a staurosporine-insensitive kinase. J Biol Chem 276:25643-25646

21. Alessi DR, Andjelkovic M, Caudwell B, Cron P, Morrice N, Cohen P, Hemmings BA 1996 Mechanism of activation of protein kinase B by insulin and IGF-1. EMBO J 15:6541-6551

22. Alessi DR, James SR, Downes CP, Holmes AB, Gaffney PR, Reese CB, Cohen P 1997 Characterization of a 3-phosphoinositide-dependent protein kinase which phosphorylates and activates protein kinase B-alpha. Curr Biol 7:261-269

23. Delcommenne M, Tan C, Gray V, Rue L, Woodgett J, Dedhar S 1998 Phosphoinositide-3-OH kinase-dependent regulation of glycogen synthase kinase 3 and protein kinase B/AKT by the integrin-linked kinase. Proc Natl Acad Sci U S A 95:1121111216

24. Fox HL, Pham PT, Kimball SR, Jefferson LS, Lynch CJ 1998 Amino acid effects on translational repressor 4E-BP1 are mediated primarily by L-leucine in isolated adipocytes. Am J Physiol Cell Physiol 275:C1232-C1238

25. Laemmli UK 1970 Cleavage of structural proteins during the assembly of the head of bacteriophage T4. Nature 227:680-685

26. Walker KS, Deak M, Paterson A, Hudson K, Cohen P, Alessi DR 1998 Activation of protein kinase B beta and gamma isoforms by insulin in vivo and by 3-phosphoinositide-dependent protein kinase-1 in vitro: comparison with protein kinase B alpha. Biochem J 331:299-308

27. Turinsky J, Damrau-Abney A 1999 Akt kinases and 2-deoxyglucose uptake in rat skeletal muscles in vivo: study with insulin and exercise. Am J Physiol 276:R277-R282

28. Frieden C 1971 Protein-protein interaction and enzymatic activity. Annu Rev Biochem 40:653-696

29. Datta K, Franke TF, Chan TO, Makris A, Yang SI, Kaplan DR, Morrison DK, Golemis EA, Tsichlis PN 1995 AH/PH domain-mediated interaction between Akt molecules and its potential role in Akt regulation. Mol Cell Biol 15:2304-2310

30. Casamayor A, Morrice NA, Alessi DR 1999 Phosphorylation of Ser-241 is essential for the activity of 3-phosphoinositide-dependent protein kinase-1: identification of five sites of phosphorylation in vivo. Biochem J 342:287-292

31. Toker A, Newton AC 2000 Cellular signaling: pivoting around PDK-1. Cell 103:185-188

32. Chan TO, Tsichlis PN 2001 PDK2: a complex tail in one Akt. Sci STKE 66:PE1

33. Feng J, Park J, Cron P, Hess D, Hemmings BA 2004 Identification of a PKB/Akt hydrophobic motif Ser-473 kinase as DNA-dependent protein kinase. J Biol Chem 279:41189-41196

34. Yoganathan TN, Costello P, Chen X, Jabali M, Yan J, Leung D, Zhang Z, Yee A, Dedhar S, Sanghera J 2000 Integrin-linked kinase (ILK): a "hot" therapeutic target. Biochem Pharmacol 60:1115-1119

35. Davis TA, Fiorotto ML, Burrin DG, Reeds PJ, Nguyen HV, Beckett PR, Vann RC, O'Connor PM 2002 Stimulation of protein synthesis by both insulin and amino acids is unique to skeletal muscle in neonatal pigs. Am J Physiol Endocrinol Metab 282:E880-890

36. Kim YB, Peroni OD, Franke TF, Kahn BB 2000 Divergent regulation of Akt1 and Akt2 isoforms in insulin target tissues of obese Zucker rats. Diabetes 49:847-856 
37. Bae SS, Cho H, Mu J, Birnbaum MJ 2003 Isoform-specific regulation of insulindependent glucose uptake by Akt/protein kinase B. J Biol Chem 278:49530-49536

38. Faridi J, Fawcett J, Wang L, Roth RA 2003 Akt promotes increased mammalian cell size by stimulating protein synthesis and inhibiting protein degradation. Am J Physio Endocrinol Metab 285:E964-E972

39. Garofalo RS, Orena SJ, Rafidi K, Torchia AJ, Stock JL, Hildebrandt AL, Coskran T, Black SC, Brees DJ, Wicks JR, McNeish JD, Coleman KG 2003 Severe diabetes, age-dependent loss of adipose tissue, and mild growth deficiency in mice lacking Akt2/PKB beta. J Clin Invest 112:197-208

40. Wray-Cahen D, Nguyen HV, Burrin DG, Beckett PR, Fiorotto ML, Reeds PJ, Weste TJ, Davis TA 1998 Response of skeletal muscle protein synthesis to insulin in suckling pigs decreases with development. Am J Physiol Endocrinol Metab 275:E602-E609
41. Storz P, Toker A 2002 3'-phosphoinositide-dependent kinase-1 (PDK-1) in PI 3-kinase signaling. Front Biosci 7:d886-d902

42. Troussard AA, Mawji NM, Ong C, Mui A, St-Arnaud R, Dedhar S 2003 Conditional knock-out of integrin-linked kinase demonstrates an essential role in protein kinase B/Akt activation. J Biol Chem 278:22374-22378

43. Sakai T, Li S, Docheva D, Grashoff C, Sakai K, Kostka G, Braun A, Pfeifer A, Yurchenco PD, Fassler R 2003 Integrin-linked kinase (ILK) is required for polarizing the epiblast, cell adhesion, and controlling actin accumulation. Genes Dev 17:926-940

44. Yue Y, Lypowy J, Hedhli N, Abdellatif M 2004 Ras GTPase-activating protein binds to Akt and is required for its activation. J Biol Chem 279:12883-12889

45. Barry FA, Gibbins JM 2002 Protein kinase B is regulated in platelets by the collagen receptor glycoprotein VI. J Biol Chem 277:12874-12878 